\title{
Studies of Cryoproteins in Systemic Lupus Erythematosus*
}

\author{
Lonnie B. Hanauer † and Charles L. Christian $\$$ \\ (From the Department of Medicine, Columbia University College of Physicians \& Surgeons, \\ and the Edward Daniels Faulkner Arthritis Clinic of the Presbyterian Hospital, \\ New York, N.Y.)
}

\begin{abstract}
Summary. Cryoproteins observed in patients with systemic lupus erythematosus were shown to be of "mixed type," consisting largely of IgG and IgM. The IgM moiety possessed anti-IgG globulin reactivity and precipitated in the cold after mixing with a source of IgG. The IgM fraction of one cryoprotein precipitated only with the same patient's IgG. Antisera prepared against purified cryoproteins regularly recognized IgM, IgG, the $11 \mathrm{~S}$ component of $C^{\prime}$, and $\alpha_{2}$-macroglobulin. $C^{\prime} 4\left(\beta_{1 E}\right)$ and $C^{\prime} 3\left(\beta_{1 \mathrm{C}}\right)$ were recognized by four and two antisera, respectively. Antisera prepared against two cryoproteins reacted (after absorption) only with the sera of origin. These "unique" antigens were associated with IgM, were destroyed by mercaptoethanol treatment, and, in one patient, were shown to disappear subsequent to clinical improvement.
\end{abstract}

\section{Introduction}

Systemic lupus erythematosus (SLE), especially when clinically active and accompanied by renal disease, has been found to be associated with low serum complement $\left(C^{\prime}\right)(1-5)$ and occasionally with serum proteins that reversibly precipitate in the cold-“cryoproteins." For cryoprecipitation to occur, a heat-labile serum factor is required. This factor is present in normal human serum and has been identified as $11 \mathrm{~S}$ material $(11 \mathrm{~S})(6)$ or the $\mathrm{C}^{\prime} 1 \mathrm{q}$ fraction of the first component of complement ( 7$)$.

The cryoproteins associated with plasma cell dyscrasias are usually monoclonal, consisting of the respective paraproteins (8). "Mixed" cryoglobulins, in contrast, consist of IgG and IgM in

* Submitted for publication August 4, 1966; accepted November 18, 1966.

Supported in part by U. S. Public Health Service research grant AM 04866 from the National Institute of Arthritis and Metabolic Diseases and a grant from the Hartford Foundation.

† Postdoctoral trainee, U. S. Public Health Service.

$\ddagger$ Recipient of investigatorship of the Health Research Council of the City of New York under contract I-178.

Address requests for reprints to Dr. Charles L. Christian, 630 West 168th St., New York, N. Y. 10032. varying proportions and have been described primarily in SLE (6), in a syndrome of purpura, weakness, and arthralgias $(8,9)$, and in other patients with varying clinical pictures (10-13).

In this report we have further characterized mixed cryoproteins of the type found in SLE. Evidence indicating the presence of multiple components of $C^{\prime}$ in purified cryoproteins is presented. Antigens unique to two patients were identified by antisera prepared against individual cryoproteins.

\section{Methods}

Blood samples obtained from patients in the Presbyterian Hospital and the Edward Daniels Faulkner Arthritis Clinic were allowed to clot in a $37^{\circ} \mathrm{C}$ water bath. Studies were performed on fresh or fresh-frozen sera $\left(-20^{\circ} \mathrm{C}\right)$. Clinical and laboratory features of the patients are summarized in Table I.

Cryoproteins were isolated by refrigerating sera at 2 to $4^{\circ} \mathrm{C}$ for 48 to 72 hours, centrifuging at $2,000 \mathrm{rpm}$ at $4^{\circ} \mathrm{C}$, and washing three times in cold isotonic saline.

Zone ultracentrifugation was performed in gradients $(10$ to $40 \%$ ) of sucrose dissolved in glycine- $\mathrm{HCl}$ buffer ( $\mathrm{pH} 3.2$ ). Cryoprecipitates were dissolved in $0.5 \mathrm{ml}$ of the glycine buffer, layered onto the sucrose gradient, and centrifuged for 15 hours at $35,000 \mathrm{rpm}$ in an SW 39 Spinco rotor. The fractions were collected from the bottom of tubes as nine samples of $0.5 \mathrm{ml}$ each and dialyzed against $\mathrm{pH} 8.0$ phosphate-buffered saline. $\mathrm{Ni}$ - 
TABLE I

Summary of clinical and laboratory features of patients

\begin{tabular}{|c|c|c|c|c|c|c|c|c|c|c|}
\hline Patient & Arthritis & Serositis & $\underset{\text { lesions }}{\text { Skin }}$ & Nephritis & Fever & $\begin{array}{c}\text { Anemia } \\
(<10 \mathrm{~g} \\
\text { hemo- } \\
\text { globin) }\end{array}$ & $\begin{array}{c}\text { Leukopenia } \\
(<5,000 \\
\text { leukocytes) }\end{array}$ & $\begin{array}{l}\text { LE prep- } \\
\text { aration } \\
\text { positive* }\end{array}$ & $\begin{array}{l}\text { Rheu- } \\
\text { matoid } \\
\text { factor } \\
\text { present }\end{array}$ & $\begin{array}{l}\text { Anti- } \\
\text { nuclear } \\
\text { antibody }\end{array}$ \\
\hline $\begin{array}{l}\text { S.L. } \\
\text { E.O. } \\
\text { J.H. } \\
\text { C.M. } \\
\text { E.B. } \\
\text { B.L. } \\
\text { L.C. } \\
\text { E.T. } \\
\text { G.F. }\end{array}$ & $\begin{array}{l}+ \\
+ \\
+ \\
+ \\
+ \\
+ \\
+ \\
+ \\
+\end{array}$ & $\begin{array}{l}+ \\
0 \\
0 \\
+ \\
+ \\
0 \\
+ \\
+ \\
0\end{array}$ & $\begin{array}{l}+ \\
+ \\
0 \\
+ \\
+ \\
+ \\
+ \\
+ \\
+\end{array}$ & $\begin{array}{l}+ \\
+ \\
0 \\
+ \\
+ \\
+ \\
+ \\
+ \\
+\end{array}$ & $\begin{array}{l}+ \\
+ \\
+ \\
+ \\
+ \\
+ \\
+ \\
+ \\
+\end{array}$ & $\begin{array}{l}+ \\
+ \\
+ \\
+ \\
+ \\
0 \\
+ \\
+ \\
+\end{array}$ & $\begin{array}{l}+ \\
+ \\
+ \\
+ \\
+ \\
0 \\
+ \\
+ \\
0\end{array}$ & $\begin{array}{l}0 \\
+ \\
0 \\
+ \\
+ \\
+ \\
+ \\
+ \\
0\end{array}$ & $\begin{array}{l}+ \\
0 \\
+ \\
0 \\
+ \\
+ \\
0 \\
0 \\
+\end{array}$ & $\begin{array}{l}+ \\
+ \\
+ \\
+ \\
+ \\
+ \\
+ \\
+ \\
+\end{array}$ \\
\hline
\end{tabular}

${ }^{*} \mathrm{LE}=$ lupus erythematosus.

trogen contents of the samples were estimated by the Folin-Ciocalteu reaction (14). IgG, IgM, and $11 \mathrm{~S}$ concentrations were measured by immunodiffusion, with Immuno-Plate ${ }^{1}$ for $\operatorname{IgG}$ and $\operatorname{IgM}$ and freshly prepared plates for $11 \mathrm{~S}$ (15). Zone centrifugation fractions were mixed in capillary tubes, refrigerated 24 hours, and examined for precipitation.

Sensitized human cells were prepared by incubating a $1 \%$ suspension of washed human $\mathrm{Rh}(\mathrm{D})+$ cells with an equal volume of diluted anti-D antisera for 45 minutes, followed by washing three times with $\mathrm{pH} 7.4$ phosphatebuffered saline and suspending in the same diluent as a $0.5 \%$ suspension. Dilutions of anti-Rh antisera were the highest that gave $4+$ antiglobulin reactions.

Analysis for kappa and lambda light chain determinants was performed by immunodiffusion with specific antisera. $^{2}$

Rabbits were immunized with isolated cryoproteins that had been washed five times in cold saline and suspended in Freund's adjuvant. Absorption of the antisera was performed with lyophilized products (pooled normal human serum, or fractions of serum). The high molecular weight fraction from zone centrifugation of one cryoprotein (S.L.) was used to immunize guinea pigs.

Immunoelectrophoresis was performed by the technique of Grabar and Williams (16).

Euglobulin preparations of sera were made by dialysis against $0.02 \mathrm{M}$ phosphate buffer ( $\mathrm{pH} 5.4$ ) overnight in the cold. Mercaptoethanol, when used, was added to a concentration of 0.1 mole per $\mathrm{L}$ and the sample dialyzed overnight against saline.

The micro-C' fixation procedure of Wasserman and Levine (17) was used to test for DNA in purified cryoproteins. The samples tested were boiled for 10 minutes in $\mathrm{pH} 11$ phosphate buffer followed by rapid chilling and neutralization (a technique shown to be adequate for denaturation of DNA) without the development of anticomplementary properties.

Antinuclear antibodies were detected by immunofluorescence, with smears of calf thymus cells and $1: 4$ dilutions

\footnotetext{
1 Hyland Laboratories, Los Angeles, Calif.

2 Provided by Dr. E. Osserman.
}

of test sera. Reactions $2+$ at that dilution or higher were considered positive.

\section{Results}

Twelve cryoprecipitates from six patients were studied by zone ultracentrifugation. A typical analysis is seen in Figure 1. There are two protein peaks : the first at tube three containing maximal IgM concentration, and the second, larger peak, generally at tube six, containing maximal IgG concentration. The $11 \mathrm{~S}$ material was found in highest concentration in the trough of the curve, fractions four and five. The cryoproteins from five of six patients studied with zone centrifugation consistently gave this pattern. Cryoprotein of one subject (S.L.) studied on two occasions showed a

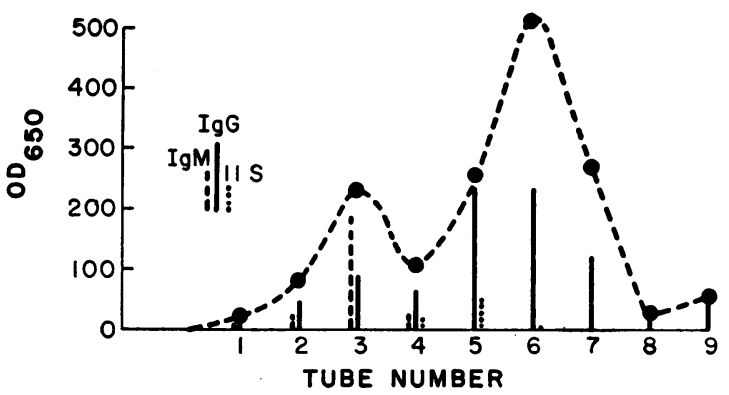

Fig. 1. Curve depicting the protein concentraTION OF ZONE CENTRIFUGATION FRACTIONS OF ACID-DISSOLVED CRYOPROTEIN OF SUBJECT E.O. Peak protein concentrations were found in tubes three and six. The bar graphs below depict the relative IgG, IgM, and $11 \mathrm{~S}$ concentrations measured by immune diffusion. The first peak was largely IgM, the second (tube six) largely $\mathrm{IgG}$, and $11 \mathrm{~S}$ material was found in the trough. Five of six cryoproteins studied in this manner exhibited this pattern. 
TABLE II

Reconstitution of cryoprecipitates: the effect of mixing zone centrifugation fractions with other fractions and other IgG sources (see Figure 1)

\begin{tabular}{|c|c|c|c|c|c|c|c|c|c|c|}
\hline Fractions: & 3 & $3+5$ & $3+6$ & $3+7$ & 6 & $3+$ FII* & $3+M_{1} \dagger$ & $6+\mathrm{FII} *$ & $6+M_{1} \dagger$ & $6+$ IgMt \\
\hline $\begin{array}{l}\text { Precipitate } \\
(0-3+\text { scale) }\end{array}$ & $\begin{array}{l}0 \\
0\end{array}$ & $\begin{array}{l}2+ \\
2+\end{array}$ & $\begin{array}{l}3+ \\
3+\end{array}$ & $\begin{array}{l}1+ \\
2+\end{array}$ & $\begin{array}{l}0 \\
0\end{array}$ & $\begin{array}{l}2+ \\
0\end{array}$ & $\begin{array}{l}2+ \\
0\end{array}$ & $\begin{array}{l}\mathbf{0} \\
\mathbf{0}\end{array}$ & $\begin{array}{l}\mathbf{0} \\
\mathbf{0}\end{array}$ & $\begin{array}{l}\mathbf{0} \\
\mathbf{0}\end{array}$ \\
\hline
\end{tabular}

${ }^{*}$ FII $=$ Cohn Fraction II.

$\dagger M_{1}=$ myeloma globulin, results identical with five myeloma sera.

$\ddagger \mathrm{IgM}=$ macroglobulinemia serum.

qualitatively similar pattern but with the high molecular weight component in excess of the low molecular weight component.

Table II summarizes the results of mixing zone centrifugation fractions obtained from cryoproteins of the type illustrated in Figure 1 and observing precipitation after refrigeration overnight. Maximal precipitation occurred on mixing the two main fractions containing IgG and IgM. Pooled Fraction II or another $\gamma$-globulin source could replace the IgG peak, but precipitation did not occur when other $\operatorname{IgM}$ paraproteins replaced the test $\operatorname{IgM}$ peak. The pattern of reactivity noted with patient E.O. was observed with cryoproteins of three other subjects. One patient (J.H., Table II), however, had an IgM peak that precipitated only with her own IgG. Pooled Fraction II and various myeloma globulins could not be substituted for her IgG peak. This necessity for autologous IgG has not been noted previously in mixed type cryoproteins.

When tested at $4^{\circ} \mathrm{C}$, IgM fractions agglutinated Ripley-sensitized human cells in low titer. (Titers at $37^{\circ} \mathrm{C}$ were generally one dilution lower.) There were notable discrepancies be-

TABLE III

\begin{tabular}{|c|c|c|}
\hline $\begin{array}{l}\text { Anti-Rh } \\
\text { eagent }\end{array}$ & $\begin{array}{c}\text { Agglutination titer } \\
\text { of IgM fraction } \\
\text { (E.O. cryoprotein) } \\
\text { for sensitized human cells }\end{array}$ & $\begin{array}{c}\text { Cryoprecipitation resulting } \\
\text { from mixing equal vol of } \\
\text { IgM fraction (E.O.) and } \\
\text { anti-Rh sera }\end{array}$ \\
\hline $\begin{array}{l}\mathrm{Mi} \\
\mathrm{Di} \\
\mathrm{Ha} \\
\mathrm{Ly} \\
\mathrm{Ru} \\
\mathrm{Al} \\
\mathrm{Ba}\end{array}$ & $\begin{array}{c}16 \\
16 \\
16 \\
16 \\
16 \\
16 \\
1: 64\end{array}$ & $\begin{array}{l}3+ \\
3+ \\
3+ \\
3+ \\
3+ \\
3+ \\
3+\end{array}$ \\
\hline
\end{tabular}

* This Table illustrates discrepancies between cryoprecipitation and agglutination of human sensitized cells. Agglutinations were performed at $37^{\circ} \mathrm{C}$. tween the agglutination reactions of the IgM fractions for human $\mathrm{Rh}$-sensitized cells and the cryoprecipitation of these fractions when mixed with the anti-Rh antisera (Table III). The Rh antisera were used in amounts that gave equivalent reactions with antiglobulin reagent, but only one of them ( $\mathrm{Ba}$, which like Ripley provides a "diagnostic coat" ${ }^{3}$ ) sensitized cells for agglutination by the IgM fraction. All of the anti-Rh antisera precipitated with the IgM fraction after refrigeration. A smaller panel of anti-Rh antisera gave

TABLE IV

Antigens recognized by antisera to cryoproteins in seven patients

\begin{tabular}{|c|c|c|c|c|c|c|c|}
\hline Patient & IgG & IgM & IgA & $\begin{array}{l}C^{\prime} 1 q \\
(11 \mathrm{~S})\end{array}$ & $\begin{array}{c}C^{\prime} \mathbf{4} \\
\left(\beta_{1 \mathrm{E}}\right)\end{array}$ & $\begin{array}{c}C^{\prime} 3 \\
\left(\beta_{1 C}\right)\end{array}$ & $a_{2} \mathbf{M}^{*}$ \\
\hline \multirow{4}{*}{$\begin{array}{l}\text { B.L. } \\
\text { L.C. } \\
\text { E.T. } \\
\text { C.M. } \\
\text { G.F. } \\
\text { S.L. } \dagger \\
\text { E.O. }\end{array}$} & \multirow{4}{*}{$\begin{array}{l}\mathrm{X} \\
\mathrm{X} \\
\mathrm{X} \\
\mathrm{X} \\
\mathrm{X} \\
\mathrm{X} \\
\mathrm{X}\end{array}$} & \multirow{4}{*}{$\begin{array}{l}\mathrm{X} \\
\mathrm{X} \\
\mathrm{X} \\
\mathrm{X} \\
\mathrm{X} \\
\mathrm{X} \\
\mathrm{X}\end{array}$} & & $X$ & $X$ & \multirow[b]{3}{*}{$\mathrm{X}$} & $X$ \\
\hline & & & & $\begin{array}{l}\mathrm{X} \\
\mathrm{X}\end{array}$ & $\mathrm{X}$ & & $\begin{array}{l}\mathrm{X} \\
\mathrm{X}\end{array}$ \\
\hline & & & & $\begin{array}{l}\mathrm{X} \\
\mathrm{X}\end{array}$ & $X$ & & $\begin{array}{l}\mathrm{X} \\
\mathrm{X}\end{array}$ \\
\hline & & & $\mathrm{X}$ & $X$ & $\mathrm{X}$ & $X$ & $X$ \\
\hline
\end{tabular}

${ }^{*} \alpha_{2} \mathrm{M}=\alpha_{2}$-macroglobulin.

$\dagger$ Antigen used for immunization was the heaviest zone centrifugation fraction. Other antisera prcduced by immunization with whole cryoproteins.

similar results with the IgM component of cryoproteins of two other subjects, i.e., precipitation with the $\operatorname{IgM}$ component but no sensitization for agglutination.

The macroglobulin fractions of five cryoproteins were analyzed for kappa or lambda light chain determinants. The IgM component of one preparation (S.L.) gave a precipitin line only with antilambda antisera. Others reacted with both types. Lipid was noted to be present in some isolated

${ }^{3}$ The term "diagnostic coat" designates the rare type of anti-Rh antisera that will sensitize cells for agglutination by the majority of sera of rheumatoid arthritis subjects. 


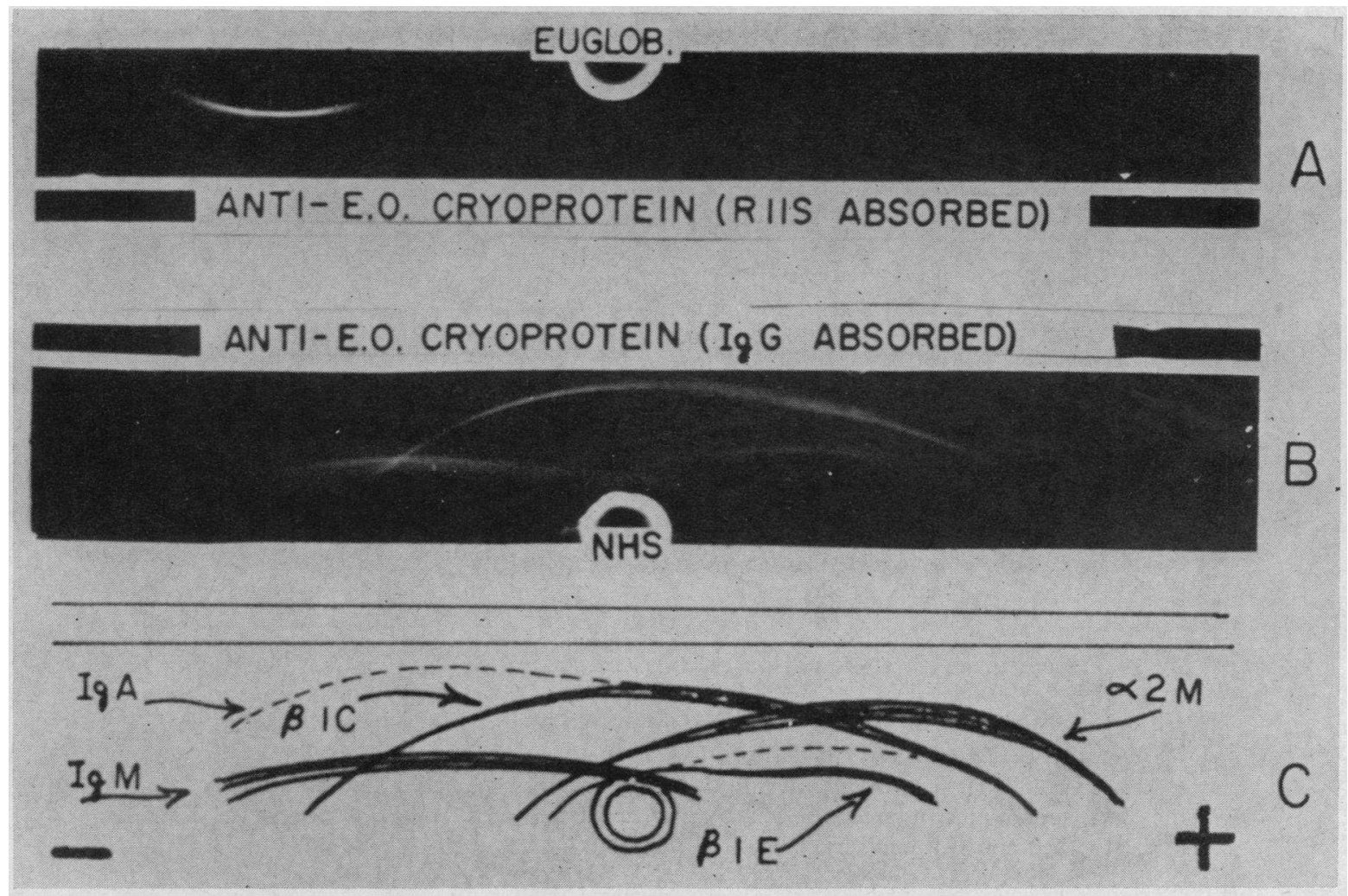

Fig. 2. IMMUNOELECTROPHORETIC PATtern. In strip B, diagrammed in strip C, the well contains normal human serum (NHS) and the trough anticryoprotein antiserum absorbed with IgG (in order to avoid a large IgG precipitin line). Precipitin lines are seen as in the diagram and explained in the text. In strip A, euglobulin is used in the well as a concentrated source of $11 \mathrm{~S}$, and the antiserum is absorbed with serum lacking $11 \mathrm{~S}$. The identity of each precipitin line was established with specific antisera or identity reactions with known antigens or both. $\alpha_{2} \mathrm{M}=\alpha_{2}-\mathrm{macro}-$ globulin.

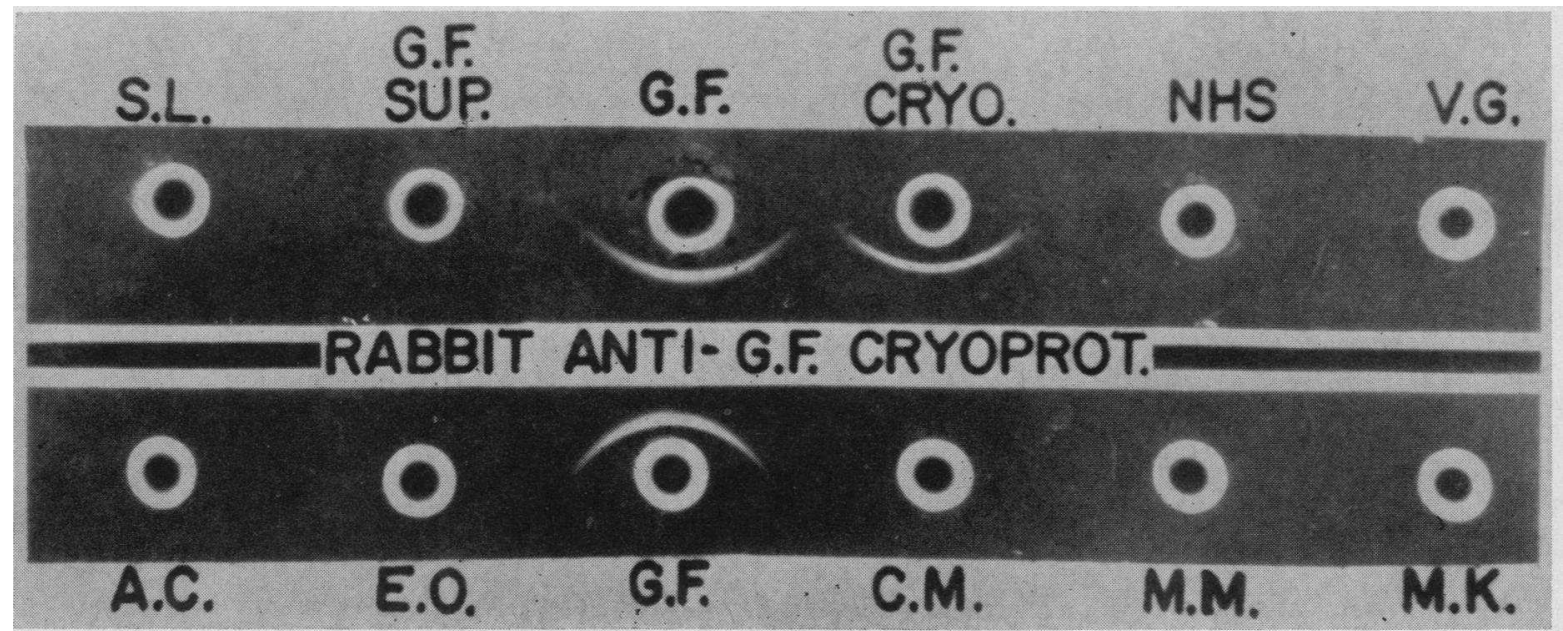

Fig. 3. Gel diffusion demonstration of "UniQue" antigen of subject G.F. The trough contains a rabbit antiserum to G.F. cryoprotein, absorbed extensively with NHS and an IgM paraprotein. Precipitin lines are seen near the wells filled with the patient's serum (G.F.) and the dissolved cryoprotein (G.F. cryo). There is no reaction with the supernatant after separation from the cryoprotein (G.F. sup), with NHS, or with the other systemic lupus erythematosus sera. 


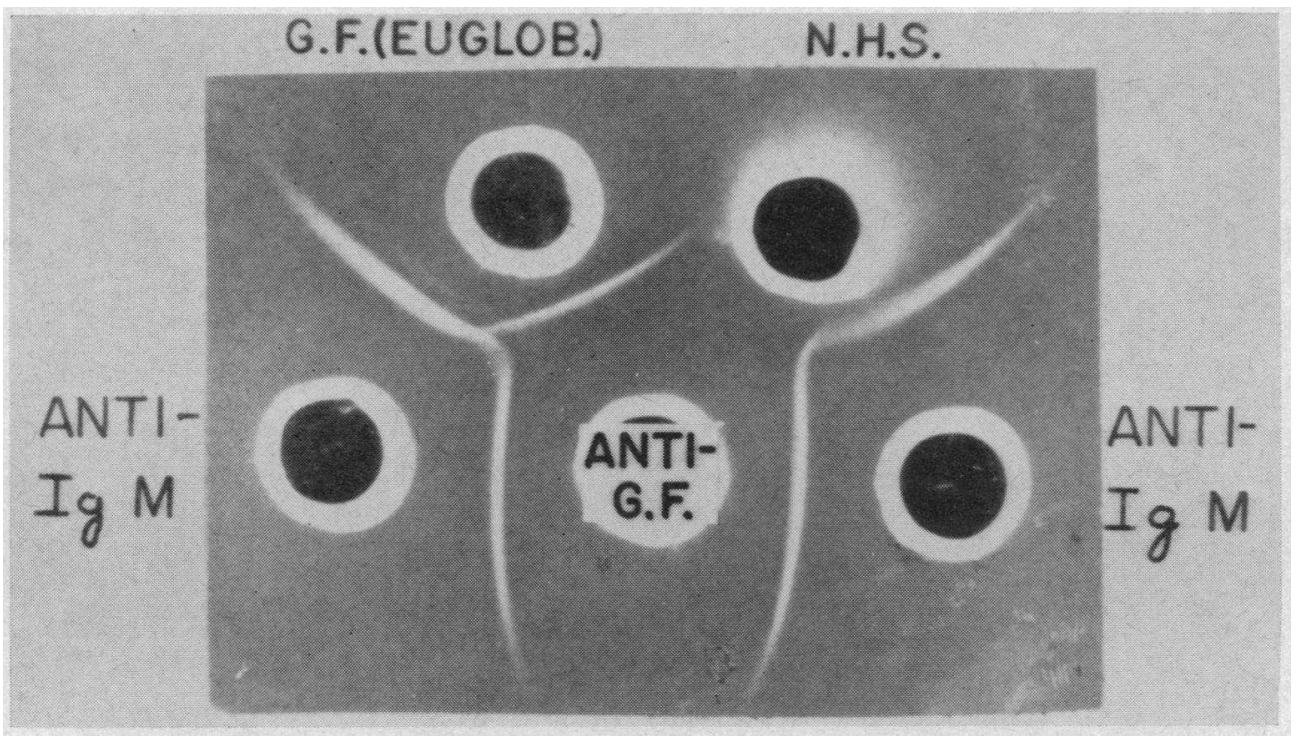

Fig. 4. Gel diffusion demonstration of the association of "Unique" antigen (G.F.) with IGM. The lower center well contains rabbit antiserum to G.F. cryoprotein, absorbed with NHS and an IgM paraprotein. This fails to form a precipitin line with NHS but forms a single line with G.F. euglobulin. This line gives a reaction of partial identity with a precipitin line between anti-IgM and the patient's IgM, failing to cross the latter line. The other precipitin lines seen represent precipitin reactions between anti-IgM and IgM present in NHS and the absorbed anti-G.F. antiserum.

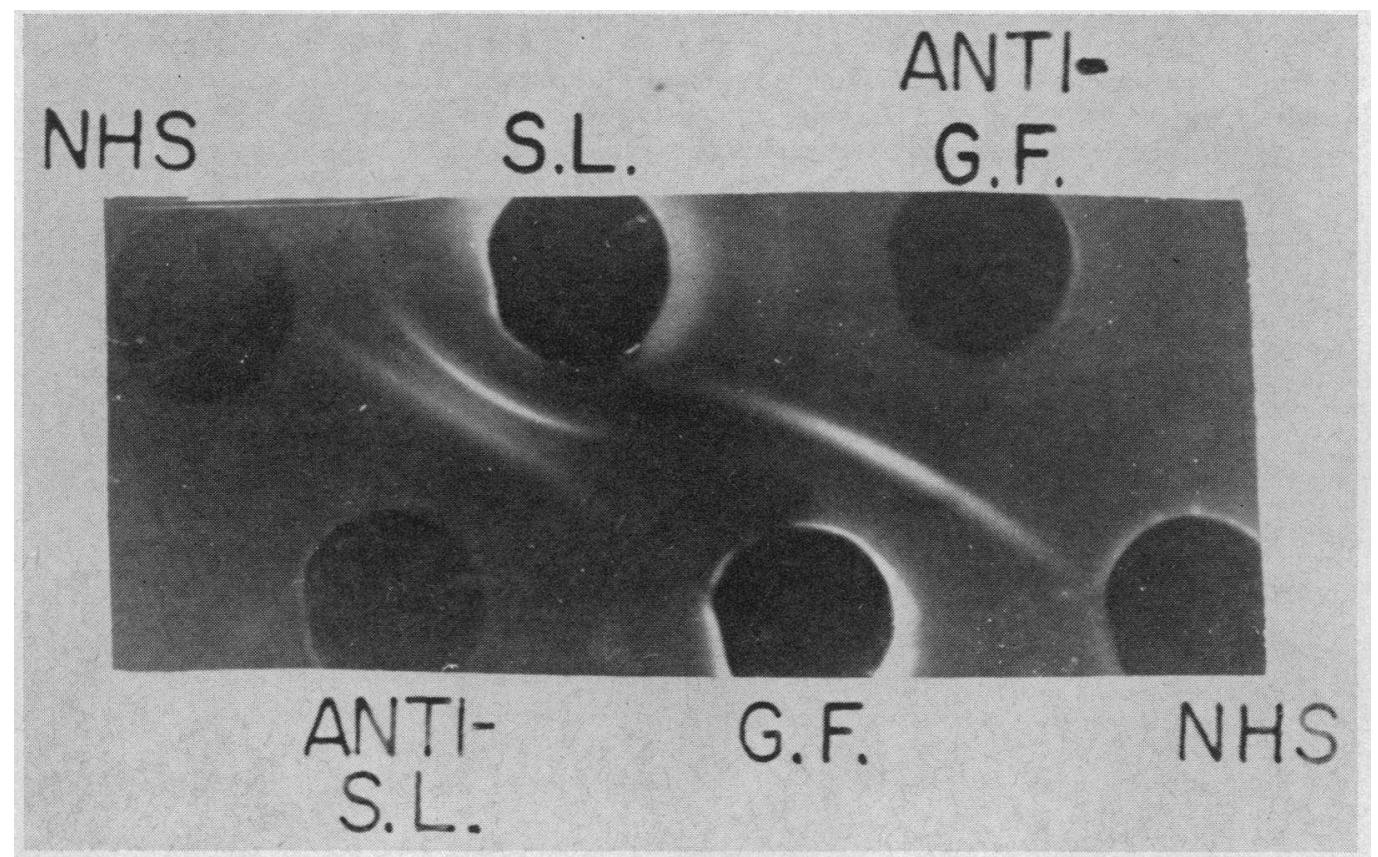

Fig. 5. Gel diffusion studies of "unique" antigens of subjects S.L. And G.F. AntiS.L. and anti-G.F. are antisera to the cryoproteins in the respective patients that have been absorbed with NHS and an IgM paraprotein. G.F. serum forms a precipitin line with anti-G.F. and S.L. serum three precipitin lines with anti-S.L., but neither antiserum reacts with NHS or with serum from the other patients. 
cryoprecipitates, appearing as a residue in the lightest zone centrifugation fraction.

A number of studies were performed on the rabbit anticryoprotein antisera. Immunoelectrophoresis utilizing antiserum specific for E.O. cryoprotein is illustrated in Figure 2. The three main classes of immunoglobulins ( $\operatorname{IgG}, \operatorname{IgM}$, and $\operatorname{Ig} \mathrm{A}$ ) are recognized. Three components of complement were identified by the antiserum: $\beta_{\mathbf{1 C}}\left(C^{\prime} 3\right)$, $\beta_{1 \mathrm{E}}\left(\mathrm{C}^{\prime} 4\right)$, and $11 \mathrm{~S}\left(\mathrm{C}^{\prime} 1 \mathrm{q}\right)$. The identity of the faint line seen above $\beta_{1 \mathrm{E}}$ in Figure 2 has not been determined. $\alpha_{2}$-Macroglobulin was also recognized. Table IV summarizes studies of antisera specific for seven different cryoproteins. IgG, $\operatorname{IgM}$, and $11 \mathrm{~S}$ were regularly identified. None of them recognized major serum antigens such as albumin or transferrin. Two of the antisera recognized antigens unique to the patients of origin after absorption with lyophilized normal human serum (NHS) and an IgM paraprotein. One pa- tient, S.L., had typical SLE. The other, G.F., died with necrotizing vasculitis but lacked classical features of any single syndrome.

The gel diffusion pattern in Figure 3 demonstrates the unique antigen in one subject. The antiserum, after extensive absorption with lyophilized NHS and a purified IgM paraprotein, recognized an antigen present only in the serum or cryoprotein from patient G.F. This unique antigen was associated with IgM as demonstrated by double diffusion (Figure 4). The reaction could not be demonstrated after treatment of the euglobulin fraction of serum G.F. with mercaptoethanol.

The second antiserum that recognized antigens unique to the patient of origin formed three precipitin lines on immunodiffusion (Figure 5). By the technique illustrated in Figure 4, the antigen forming the line closest to the antibody well was shown to be associated with IgM. The two other lines could not be evaluated in this respect. Ap-

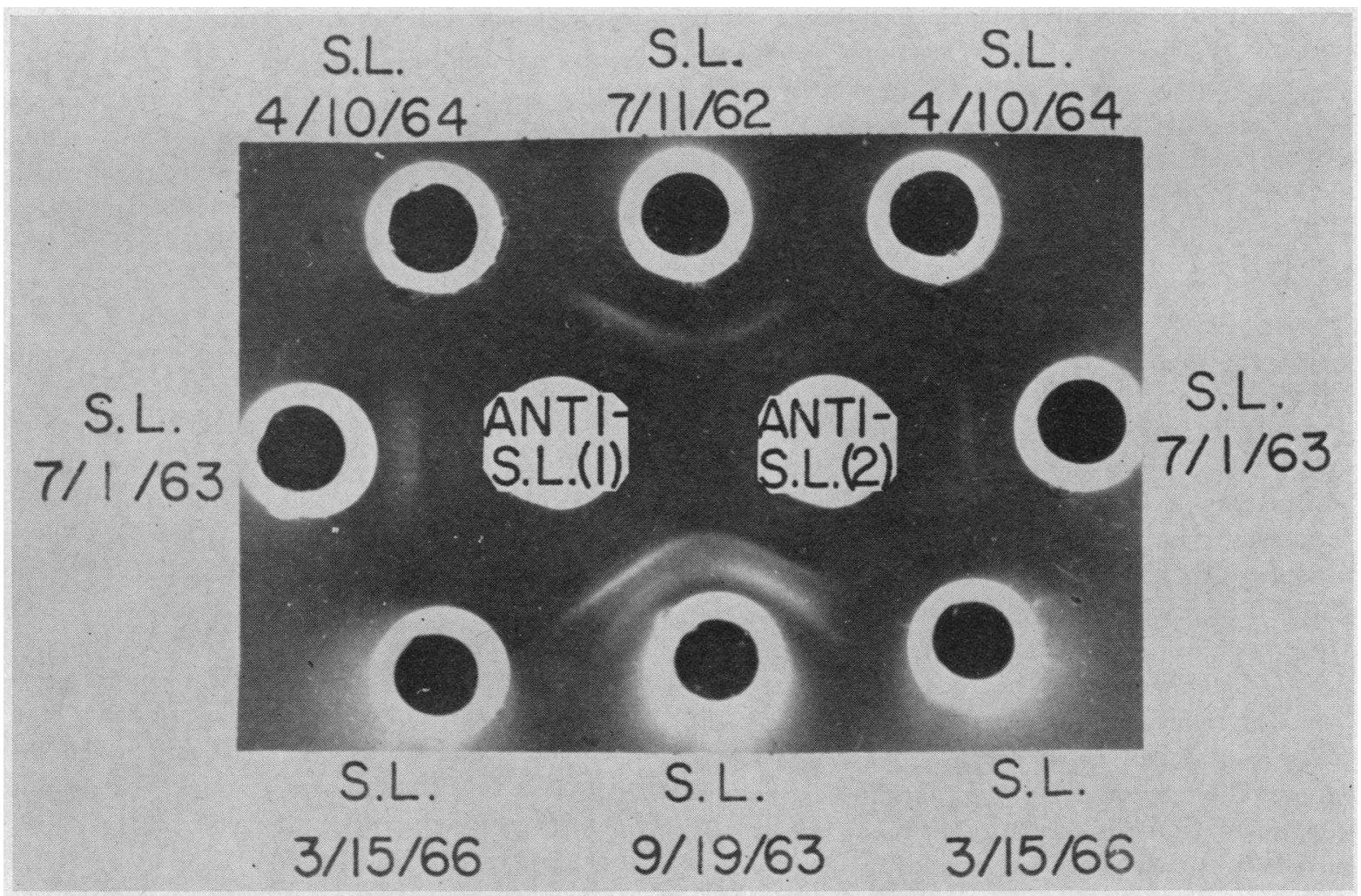

Fig. 6. Gel diffusion analysis of "Unique" antigens in Serial samples of S.L. Sera. The center wells were filled with two guinea pig antisera to the high molecular weight fraction of cryoprotein isolated from patient S.L. in September 1963. The antisera are absorbed with NHS and an IgM paraprotein. Weak precipitin lines are formed against sera drawn from the patient in July 1962 and July 1963 . There is a strong, multiphasic reaction against sera drawn in September 1963 and no reaction against sera drawn in 1964 and 1966. 
pearance and disappearance of the unique antigens in patient S.L. were shown to correlate with the clinical state and the presence of cryoproteinemia (Figure 6). In September 1963, when the patient was most severely ill, she had large amounts of cryoprotein, and antiserum prepared against her cryoprotein isolated at this time recognized three antigenic determinants unique to the patient. Sera drawn before this time reacted weakly with the antisera. One and 3 years later, the patient had improved clinically and had no measurable cryoprotein, and her serum gave no precipitin reaction with the absorbed antiserum.

The antisera used for demonstration of the unique determinants in subjects G.F. and S.L. were, in each case, absorbed with lyophilized pooled normal human serum and with a purified IgM paraprotein. With these antisera, in the gel diffusion technique illustrated in Figure 3,25 SLE sera, 12 IgM paraproteins (from subjects with primary macroglobulinemia), and 15 sera from patients with miscellaneous illnesses were studied. None gave visible reactions. Antisera prepared against cryoproteins of six other subjects did not recognize unique antigens.

\section{Discussion}

The cryoproteins studied in this report were found to contain IgG and IgM resembling the mixed cryoproteins first described by LoSpalluto, Dorward, Miller, and Ziff (10) and recently studied by Meltzer, Franklin, and others $(8,9,11-13)$. Patients in the present study, however, had clinical and laboratory pictures consistent with SLE rather than less clearly defined syndromes (purpuras, fatigue, and arthralgias) (9). All of our nine patients (Table I) had arthritis and fever. Eight had skin lesions, evidence of renal involvement, and anemia, and seven had some degree of leukopenia. Six had positive LE preparations on one or more occasions. The three patients with negative LE preparations had positive immunofluorescent tests for antinuclear factor. Rheumatoid factor, on the other hand, present in all eleven of Meltzer's patients with mixed cryoglobulins (8), was found in only five of the patients in this series. The cryoproteins associated with SLE also differed in that they contained larger amounts of $\operatorname{IgG}$ than $\operatorname{IgM}$ and required a heat-labile component of $\mathrm{C}^{\prime}(11 \mathrm{~S})$ for precipitation.

Do the cryoproteins observed in SLE have pathogenetic significance? They are observed in patients with active disease, especially glomerulitis, in association with low serum $\mathrm{C}^{\prime}$ levels and anticomplementary sera, and at least one component of $C^{\prime}\left(C^{\prime} 1 q\right)$ has been shown to participate in their formation. In the present study, antisera specific for cryoproteins recognized $\beta_{1 \mathrm{C}^{-}}$and $\beta_{1 \mathrm{E}^{-}}$ globulins. It can be postulated that immune aggregates mediate vasculitis in SLE in a manner similar to their role in experimental serum sickness (18). As attractive as this thesis may be (and consistent with many observations of SLE subjects), it must be admitted that the hypothetical antigen-antibody complexes have not been characterized. One can postulate that the IgM in mixed cryoproteins and the IgG with which it reacts provide all the reactants necessary for the formation of an immune complex, but it must also be considered that the anti- $\gamma$-globulin IgM components are coprecipitated by some unidentified immune complex in a fashion similar to the coprecipitation of $\mathrm{C}^{\prime}$ components. It is notable that conventional anti- $\gamma$-globulin activity of purified IgM fractions of cryoproteins, as measured by hemagglutination reactions (Table III), was weak, in the face of striking precipitation when these fractions were incubated with IgG in the cold. The observed discrepancy between cryoprecipitation of anti-Rh sera when added to the IgM component of cryoproteins and the failure of the anti-Rh reagents to sensitize cells for agglutination by the IgM fractions might be explained on the basis of genetic heterogeneity of IgG. There is evidence in man (19) and rabbit $(20,21)$ that the complete spectrum of genetic types of IgG demonstrable in an individual whole serum may not be present in purified antibodies. In the present studies, the anti-Rh antibodies might have been deficient in the type of IgG with which the cryoprotein IgM fraction was reactive. [Deletions of genetic factors have been described in IgG anti$\mathrm{Rh}$ antibodies $(22,23)$.

In part, the present study was directed at the hypothesis that cryoproteins contain some antigen in the form of an immune complex. Antisera specific for individual cryoproteins might detect the 
hypothetical antigen in the immune complex. The demonstration that antisera absorbed with large amounts of normal human sera did detect antigens unique to the two subjects, however, is difficult to interpret. In both cases, the unique antigens could not be dissociated from IgM. The most likely explanation is that these antigens are unique intrinsic determinants on $\operatorname{IgM}$ molecules. Similar studies utilizing antisera specific for monoclonal paraproteins have demonstrated specificity for unique determinants of paraproteins, which in the case of IgM paraproteins may be destroyed by mercaptoethanol treatment $(24,25)$. In the present study, however, only one of five cryoglobulins tested had an IgM component with monoclonal characteristics, i.e., single L-chain determinants. The antiserum specific for S.L. IgM component recognized three antigens by gel diffusion, and all three antigens disappeared over the period of observation. The possibility that the unique antigens are of environmental origin (microbial or otherwise) and are merely associated with IgM still exists, but no direct evidence can be cited in its support. Lee and Rivero presented some evidence for the presence of DNA in the cryoprotein of one SLE subject (26), but comparable studies by the authors have been negative, and DNA was not detected in the cryoprotein of subject S.L. when studied with a microcomplement fixation procedure that was capable of measuring as little as $1 \mu \mathrm{g}$ of DNA.

An explanation for the regular reactivity of anticryoprotein antisera with $\alpha_{2}$-macroglobulin is lacking.

\section{References}

1. Townes, A. S., and C. R. Stewart, Jr. Estimations of the second component and third component complex of complement in the serum of patients with systemic lupus erythematosus. Bull. Johns Hopk. Hosp. 1965, 117, 348.

2. Vaughan, J. H., T. B. Bayles, and C. B. Favour. Response of serum gamma globulin levels and complement titer to adrenocorticotropic hormone (ACTH) therapy in lupus erythematosus disseminatus. J. Lab. clin. Med. 1951, 37, 698.

3. Ellis, H. A., and D. Felix-Davies. Serum complement, rheumatoid factor, and other serum proteins in rheumatoid disease and systemic lupus erythematosus. Ann. rheum. Dis. 1959, 18, 215.

4. Williams, R. C., Jr., and D. H. Law IV. Serum complement in connective tissue disorders. J. Lab. clin. Med. 1958, 52, 273.

5. Morse, J. H., H. J. Müller-Eberhard, and H. G. Kunkel. Antinuclear factors and serum complement in systemic lupus erythematosus. Bull. N. Y. Acad. Med. 1962, 38, 641.

6. Christian, C. L., W. B. Hatfield, and P. H. Chase. Systemic lupus erythematosus. Cryoprecipitation of sera. J. clin. Invest. 1963, 42, 823.

7. Lepow, I. H., G. B. Naff, E. W. Todd, J. Pensky, and C. F. Hinz, Jr. Chromatographic resolution of the first component of human complement into three activities. J. exp. Med. 1963, $117,983$.

8. Meltzer, M., and E. C. Franklin. Cryoglobulinemia -a study of twenty-nine patients. I. IgG and IgM cryoglobulins and factors affecting cryoprecipitability. Amer. J. Med. 1966, 40, 828.

9. Meltzer, M., E. C. Franklin, K. Elias, R. T. McCluskey, and N. Cooper. Cryoglobulinemia-a clinical and laboratory study. II. Cryoglobulins with rheumatoid factor activity. Amer. J. Med. $1966,40,837$.

10. LoSpalluto, J., B. Dorward, W. Miller, Jr., and M. Ziff. Cryoglobulinemia based on interaction between a gamma macroglobulin and $7 \mathrm{~S}$ gamma globulin. Amer. J. Med. 1962, 32, 142.

11. Costanzi, J. J., C. A. Coltman, Jr., D. A. Clark, J. I. Tennenbaum, and D. Criscuolo. Cryoglobulinemia associated with a macroglobulin. Studies of a 17.5S cryoprecipitating factor. Amer. J. Med. 1965, 39, 163.

12. Peetoom, F., and E. van Loghem-Langereis. IgMIgG $\left(\beta_{2} \mathrm{M}-7 \mathrm{~S} \gamma\right)$ cryoglobulinaemia. An auto-immune phenomenon. Vox Sang. (Basel) 1965, 10, 281.

13. Balázs, V., and M. M. Fröhlich. Anticomplementary effect of cryoglobulinemic sera and isolated cryoglobulins. Amer. J. med. Sci. 1966, 251, 89.

14. Heidelberger, M., and C. F. C. MacPherson. Quantitative microestimation of antibodies in the sera of man and other animals. Science 1943, 97, 405. and 98,63 .

15. Hanauer, L. B., and C. L. Christian. Clinical studies of hemolytic complement and the 11S component. Amer. J. Med. In press.

16. Grabar, P., and C. A. Williams. Méthode permettant l'étude conjuguée des propriétés électrophorétiques et immunochimiques d'un mélange de protéines. Application au sérum sanguin. Biochim. biophys. Acta (Amst.) 1953, 10, 193.

17. Wasserman, E., and L. Levine. Quantitative microcomplement fixation and its use in the study of antigenic structure by specific antigen-antibody inhibition. J. Immunol. 1961, 87, 290.

18. Dixon, F. J. The role of antigen-antibody complexes in disease. Harvey Lect. 1962-63, 58, 21. 
19. Allen, J. C., H. G. Kunkel, and E. A. Kabat. Studies on human antibodies. II. Distribution of genetic factors. J. exp. Med. 1964, 119, 453.

20. Gell, P. G. H., and A. Kelus. Deletions of allotypic $\gamma$-globulins in antibodies. Nature (Lond.) 1962, 195, 44.

21. Rieder, R. F., and J. Oudin. Studies on the relationship of allotypic specificities to antibody specificities in the rabbit. J. exp. Med. 1963, 118, 627.

22. Mårtenson, L. Distribution of Gm-specificities among the gamma globulin molecules (abstract). Acta path. microbiol. scand. 1962, 54, 343.
23. Harboe, M. Interactions between red cells coated with incomplete anti-D and rheumatoid sera. Acta path. microbiol. scand. 1960, 50, 383.

24. Harboe, M., J. Deverill, and H. C. Godal. Antigenic heterogeneity of Waldenström type $\gamma \mathrm{M}$-globulins. Scand. J. Haemat. 1965, 2, 137.

25. Morse, J. H. Personal communication.

26. Lee, S. L., and I. Rivero. Cryoglobulins in systemic lupus erythematosus (SLE) as circulating immune complexes (abstract). Arth. and Rheum. 1964, 7, 321. 